\title{
Serum Asunaprevir and Daclatasvir Concentrations and Outcomes in Patients with Recurrent Hepatitis C Who Have Undergone Living Donor Liver Transplantation
}

\author{
NOBORU HARADA ${ }^{1}$, TOMOHARU YOSHIZUMI ${ }^{1}$, TORU IKEGAMI ${ }^{1}$, SHINJI ITOH ${ }^{1}$, NORIHIRO FURUSHO ${ }^{2}$, \\ MASAKI KATO $^{3}$, SHINJI SHIMODA ${ }^{4}$, TAKASUKE FUKUHARA ${ }^{5}$, YUJI SOEJIMA ${ }^{1}$ and YOSHIHIKO MAEHARA ${ }^{1}$ \\ ${ }^{1}$ Department of Surgery and Medical Science, Graduate School of Medical Sciences, \\ Kyushu University, Fukuoka, Japan; \\ ${ }^{2}$ Department of General Internal Medicine, Kyushu University, Fukuoka, Japan; \\ ${ }^{3}$ Department of Medicine and Bioregulatory Science, \\ Graduate School of Medical Sciences, Kyushu University, Fukuoka, Japan; \\ ${ }^{4}$ Department of Medicine and Biosystemic Science, Kyushu University, Fukuoka, Japan; \\ ${ }^{5}$ Department of Molecular Virology, Research Institute for Microbial Diseases, Osaka University, Osaka, Japan
}

\begin{abstract}
Background/Aim: This study's aim was to investigate the safety and effectiveness of asunaprevir and daclatasvir treatment for recurrent hepatitis $C$ virus $(H C V)$ infection in transplant recipients. The study cohort comprised 14 transplant recipients with recurrent hepatitis $C$ who were receiving asunaprevir and daclatasvir. Patients and Methods: Serum concentrations of asunaprevir and daclatasvir, their therapeutic effects, trough concentrations/dose ratios of tacrolimus, and adverse effects were evaluated. Results: Hepatitis $C$ virus was still undetectable in 12 (85.7\%) out of 14 patients 12 weeks after completing treatment. One week after starting treatment, asunaprevir concentrations were significantly higher in patients with baseline albumin concentrations $\leq 3.6 \mathrm{~g} / \mathrm{dl}$ than in those with baseline albumin concentrations $>3.6 \mathrm{~g} / \mathrm{dl}$. No marked fluctuations were identified in tacrolimus trough concentrations/dose ratios during the 24 weeks of therapy. Conclusion: Full doses of asunaprevir and daclatasvir-based treatment can be safely and effectively administered to liver transplant recipients for recurrent $H C V$ genotype $1 \mathrm{~b}$ after living donor liver transplantation (LDLT) with little effect on blood concentrations of tacrolimus.
\end{abstract}

Correspondence to: Noboru Harada, MD, Ph.D., Department of Surgery and Medical Science, Graduate School of Medical Sciences, Kyushu University, 3-1-1 Maidashi, Higashi-ku, Fukuoka, 812-8582, Japan. Tel: +81 926425466, Fax: +81 926425482, e-mail: nharada@surg2.med.kyushu-u.ac.jp

Key Words: Sustained virological response, direct-acting antiviral, liver transplantation, tacrolimus, genotype $1 \mathrm{~b}$.
Hepatitis C virus (HCV) has infected 130-170 million people worldwide and those with chronic hepatitis and cirrhosis are at high risk for hepatocellular carcinoma (1). Until 2011, the standard-of-care treatment for genotype $1 \mathrm{HCV}$ was dualtherapy with pegylated interferon (PEG IFN) and ribavirin (RBV). However, in patients with genotype $1 \mathrm{HCV}$ infection, this treatment produced a sustained viral response (SVR) in only approximately $50 \%$ of patients $(2,3)$.

Recurrence of $\mathrm{HCV}$ infection after living donor liver transplantation (LDLT) is currently a major cause of morbidity and allograft loss (4). Because the outcome of administering classic PEG IFN/RBV antiviral therapy postLDLT is at most moderate with respect to SVR, these patients remain a difficult-to-treat group (5-7). Consequently, much effort has gone into the development of new treatments for $\mathrm{HCV}$, leading to the approval of first-generation directacting antivirals (DAAs). Several IFN-free DAA therapies have recently been developed; these have achieved improved SVR rates and a shorter duration of therapy for patients with chronic hepatitis $\mathrm{C}$ worldwide $(8,9)$. DAA combination therapies such as sofosbuvir (nucleotide NS5B polymerase inhibitor) plus ledipasvir (NS5A replication complex inhibitor), ombitasvir (NS5A replication complex inhibitor), paritaprevir (NS3/4A protease inhibitor), and dasabuvir (nonnucleotide NS5B polymerase inhibitor) plus ribavirin, and sofosbuvir plus daclatasvir (NS5A replication complex inhibitor) have achieved significant improvements in the efficacy and safety for patients with recurrent HCV after LT (10-12). In Japan, daclatasvir and asunaprevir (NS3/4A protease inhibitors) combination treatment has been used since its approval in 2014 (13). Cyclosporine A, via inhibition of organic anion transporting polypeptide $1 \mathrm{Ba}$, has 
the potential to decrease liver uptake of asunaprevir. However, the risk of drug-drug interactions between asunaprevir and daclatasvir and immunosuppressive agents other than cyclosporine A remains unclear.

Consequently, we investigated both the associations between serum concentrations of asunaprevir and daclatasvir with sustained virological response and trough concentrations of tacrolimus during treatment for recurrent hepatitis $\mathrm{C}$ after LDLT.

\section{Patients and Methods}

Patients and surgery. Patients with recurrent hepatitis $\mathrm{C}$ after undergoing LDLT in the Department of Surgery and Science, Graduate School of Medical Sciences, Kyushu University, were considered for antiviral therapy with combined asunaprevir and daclatasvir if a posttransplant biopsy of the allograft showed recurrent hepatitis $\mathrm{C}$ with Stage 2 or higher fibrosis or Grade 2 or higher lobular hepatitis according to Scheuer's classification system (14). Patients with any of the following factors were ineligible for this therapy: (i) recent acute cellular rejection, (ii) hemoglobin $(\mathrm{Hb})$ concentration less than $10.0 \mathrm{~g} / 1$, and (iii) non-genotype $1 \mathrm{~b} \mathrm{HCV}$. Of the 184 consecutive patients with recurrent hepatitis $\mathrm{C}$ after LDLT treated at Kyushu University between October 1996 and August 2014, 14 met the above criteria and were prospectively enrolled in this study. The surgical procedures performed on the donors and recipients are described elsewhere (15-17). Written informed consent was obtained from all patients regarding the treatment. The Ethics and Indications Committee of Kyushu University approved all procedures involving LDLT. The Institutional Review Board of Kyushu University approved this study (approval number: 26-233). The study protocol conformed to the ethical guidelines of the 1975 Helsinki Declaration.

Antiviral therapy. Daclatasvir (Daklinza; Bristol-Myers Squibb, New York, NY, USA) $60 \mathrm{mg}$ was administered once a day in combination with asunaprevir (Sunvepra; Bristol-Myers Squibb) $100 \mathrm{mg}$ twice a day for 24 weeks. Serum concentrations of daclatasvir and asunaprevir were assayed by Tandem Labs (West Trenton, NJ, USA) using validated liquid chromatography with tandem mass spectrometry methods during the period of known analyte stability. The methods used in these assays have been published previously $(18,19)$. Serum samples were frozen at $80^{\circ} \mathrm{C}$ within $4 \mathrm{~h}$ of collection and thawed at the time of measurement. Serum daclatasvir and asunaprevir concentrations were measured 1 , 4, and 12 weeks after starting treatment. Treatment was discontinued in the event of viral breakthrough.

HCV RNA and virological responses. Serum HCV RNA titers were determined by real-time HCV assay (AccuGene HCV; Abbot Molecular, Des Plaines, IL, USA). The lower and higher quantification limits of this assay were $1.08 \log _{10}$ and $8.00 \log _{10}$ $\mathrm{IU} / \mathrm{ml}$, respectively. Virological responses were categorized as endof-treatment virological response (ETVR) and sustained virological response (SVR). SVR12 was defined as HCV-RNA maintained below the lower limit of detection 12 weeks after drug discontinuation in patients who had achieved a virological response at the end of treatment, and recurrence was defined as HCV-RNA above the lower limit of quantification.
Table I. Patient background characteristics.

\begin{tabular}{lc}
\hline Variables & $(\mathrm{n}=14)$ \\
\hline Age (years) at enrollment & $66(57-78)$ \\
Gender (Male/ Female; $\mathrm{n})$ & $1 / 13$ \\
Height $(\mathrm{cm})$ & $155 \pm 1.5$ \\
Weight $(\mathrm{kg})$ & $49 \pm 2.1$ \\
Body mass index $\left(\mathrm{kg} / \mathrm{m}^{2}\right)$ & $21(16-27)$ \\
Left lobe graft, yes & $8(57.1)$ \\
Albumin (mg/dl) & $3.6 \pm 0.1$ \\
History of interferon, yes & $9(64.3)$ \\
HCV RNA (logI $10 \mathrm{U} / \mathrm{ml})$ & $6.5 \pm 0.2$ \\
Recipient IL-28B (rs8099917), TT & $13(92.9)$ \\
Donor IL-28B (rs8099917), TT & $12(85.7)$ \\
Fibrosis score F1/F2/F3/F4 & $6 / 4 / 3 / 1$ \\
\hline
\end{tabular}

HCV: Hepatitis C virus; IL: interleukin; F: fibrosis. Values are expressed as mean (range), mean \pm standard error, or number (percentage).

Administration of tacrolimus during antiviral therapy. Because cyclosporine A potentially decreases liver uptake of asunaprevir, tacrolimus was administered to all patients after LDLT as the treatment of choice during antiviral therapy. During antiviral therapy, the tacrolimus dose was reduced to maintain trough concentrations of $4-10 \mathrm{ng} / \mathrm{ml}$.

Diagnoses and definition. Patients with abnormal liver function tests, including high serum transaminase with or without high total bilirubin titers, underwent radiological studies to rule out vascular or biliary complications. Patients whose imaging ruled out vascular or biliary complications, underwent percutaneous liver biopsy. Acute cellular rejection (ACR) was defined as the presence of mixed lymphocyte aggregations with bile duct damage and vascular endotheliitis (20).

Statistical analyses. Continuous data are expressed as the mean \pm standard error. Quantitative and categorical variables were compared using the Wilcoxon rank-sum test and Fisher's exact test, respectively. The cut-off concentration for serum albumin was set as the mean concentration. $p<0.05$ was considered to denote statistical significance. All statistical analyses were performed using JMP software version Pro12 (SAS Institute, Cary, NC, USA).

\section{Results}

Patient characteristics. The background characteristics of the 14 patients treated with combined asunaprevir and daclatasvir are summarized in Table I. The study cohort comprised one man and 13 women ranging in age from 57 to 78 years (mean 66 years). Nine patients $(64.3 \%)$ had a history of IFN therapy: two had been treated with simeprevir and PEG IFN plus RBV and seven with PEG IFN plus RBV. The mean pre-treatment serum HCV-RNA titer was $6.5 \log 10 \mathrm{IU} / \mathrm{ml}$. All 14 patients had Grade 2 hepatitis, and the following grades of fibrosis: F1, $\mathrm{n}=6 ; \mathrm{F} 2, \mathrm{n}=4 ; \mathrm{F} 3, \mathrm{n}=3$; and $\mathrm{F} 4, \mathrm{n}=1$. 
a. Asunaprevir and tacrolimus

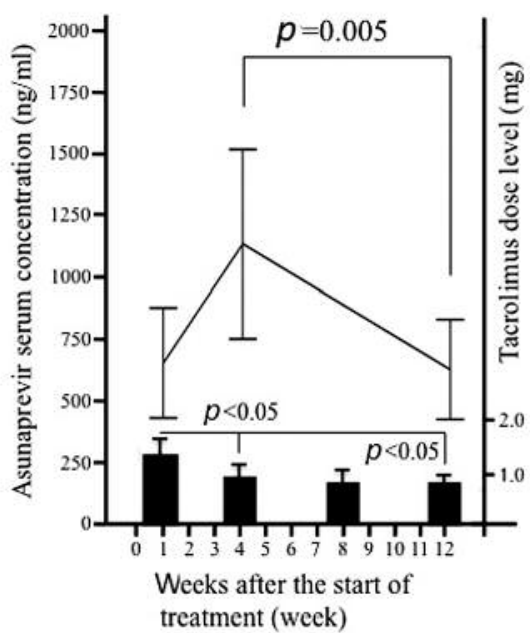

b. Daclatasvir and tacrolimus

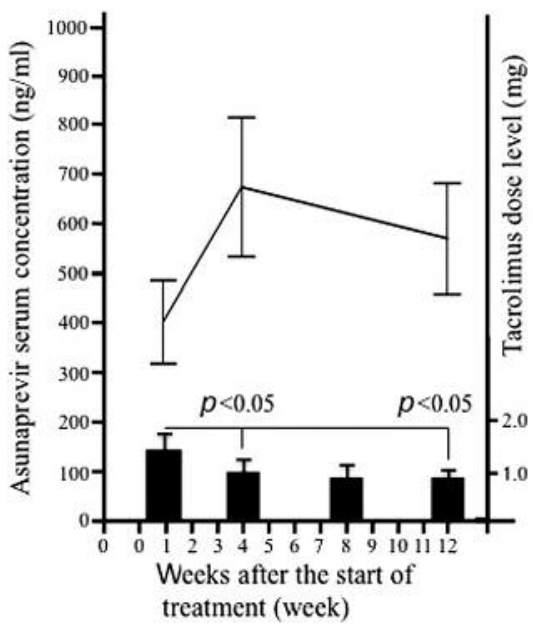

Figure 1. Changes in serum concentrations of asunaprevir and daclatasvir in patients with recurrent HCV after living donor liver transplantation. a. Changes in serum concentrations of asunaprevir $(\mathrm{ng} / \mathrm{ml})$ after starting therapy. The serum concentration of asunaprevir was significantly greater 4 weeks than 12 weeks after completing treatment $(p=0.005)$. Changes in tacrolimus dose after the start of treatment were also indicated. The tacrolimus dose was significantly lower 4 weeks after treatment $(0.9 \pm 0.2 \mathrm{mg} /$ day) than before treatment (1.4 $\pm 0.3 \mathrm{mg} /$ day, $p=0.01)$. The tacrolimus dose 24 weeks after treatment $(0.7 \pm 0.2 \mathrm{mg} /$ day) was significantly lower than before treatment $(1.4 \pm 0.3 \mathrm{mg} /$ day, $\mathrm{p}=0.005)$. $\mathrm{b}$. Changes in serum concentrations of daclatasvir $(\mathrm{ng} / \mathrm{ml})$ after starting therapy. Data are expressed as mean \pm standard error $1,4,12$ weeks after the start of treatment. Changes in tacrolimus dose after the start of treatment were also indicated. The tacrolimus dose was significantly lower 4 weeks after treatment $(0.9 \pm 0.2 \mathrm{mg} /$ day) than before treatment $(1.4 \pm 0.3 \mathrm{mg} /$ day, $p=0.01)$. The tacrolimus dose 24 weeks after treatment $(0.7 \pm 0.2 \mathrm{mg} /$ day) was significantly lower than before treatment $(1.4 \pm 0.3 \mathrm{mg} /$ day, $p=0.005)$.

Serum concentrations of asunaprevir and daclatasvir. Serum concentrations (mean \pm standard error) of asunaprevir 1,4 , and 12 weeks after starting treatment were $573 \pm 248$, $1,108 \pm 426$, and $543 \pm 225 \mathrm{ng} / \mathrm{ml}$, respectively Figure 1a). There were no significant differences in serum asunaprevir concentrations between 1 and 4 weeks or between 1 and 12 weeks. However, the serum asunaprevir concentration at 4 weeks was significantly greater than that at 12 weeks $(p=0.005)$. Serum daclatasvir concentrations (mean \pm standard error) 1,4 , and 12 weeks after starting treatment were $406 \pm 82,672 \pm 138$, and $571 \pm 109 \mathrm{ng} / \mathrm{ml}$, respectively (Figure 1b). There were no significant differences between the daclatasvir concentrations at these three time points.

One week after starting treatment, asunaprevir concentrations were significantly higher in patients with baseline albumin concentrations $\leq 3.6 \mathrm{~g} / \mathrm{dl}$ than in those with baseline albumin concentrations $>3.6 \mathrm{~g} / \mathrm{dl}(p=0.03$, Figure 2a). Additionally, one week after starting treatment, daclatasvir concentrations in patients with baseline albumin concentrations $\leq 3.6 \mathrm{~g} / \mathrm{dl}(\mathrm{n}=8)$ tended to be higher than those in patients with baseline albumin concentrations $>3.6 \mathrm{~g} / \mathrm{dl}$ $(\mathrm{n}=6 ; p=0.09$, Figure 2b).

Tacrolimus dose, trough concentration, and trough/dose ratio. The tacrolimus dose 4 weeks after starting treatment
$(0.9 \pm 0.2 \mathrm{mg} /$ day $)$ was significantly lower than that before treatment $(1.4 \pm 0.3 \mathrm{mg} /$ day, $p<0.05$, Figure $1 \mathrm{a}$ and $\mathrm{b})$. The tacrolimus dose $(0.7 \pm 0.2 \mathrm{mg} /$ day $)$ at 12 weeks of treatment was significantly lower than that before treatment $(1.4 \pm 0.3$ $\mathrm{mg} /$ day, $p<0.05$, Figure $1 \mathrm{a}$ and $\mathrm{b}$ ). The tacrolimus trough concentration after 24 weeks of treatment $(3.5 \pm 0.5 \mathrm{ng} / \mathrm{ml})$ was also significantly lower than that before treatment $(6.5 \pm 0.9 \mathrm{ng} / \mathrm{ml}, \quad p=0.003)$. The tacrolimus trough concentration of the patient with liver cirrhosis (F4) tended to be higher than those of the patients without liver cirrhosis (Figure 3a). Overall, there was no significant difference between tacrolimus trough concentration/dose ratio before treatment $(5.9 \pm 1.0 \mathrm{ng} / \mathrm{ml} / \mathrm{mg})$ and that at 24 weeks $(6.4 \pm 1.0$ $\mathrm{ng} / \mathrm{ml} / \mathrm{mg}$, Figure $3 \mathrm{~b}$ ).

Treatment outcomes and tolerability. Of the 14 studied patients, 13 completed the treatment protocol, whereas one discontinued treatment because of absence of virological response $(n=1)$ followed by viral breakthrough $(n=1$, Figure $4 a)$. Figure $4 \mathrm{~b}$ shows the percentage of patients in whom HCV-RNA became undetectable in serum as a result of asunaprevir and daclatasvir-based therapy. HCV-RNA became undetectable in serum within 16 weeks in $92.9 \%$ of patients. ETVR was achieved in 13 patients $(92.9 \%)$ and SVR12 in 12 patients $(85.7 \%)$. There were no significant 


\section{a. Asunaprevir (1week)}

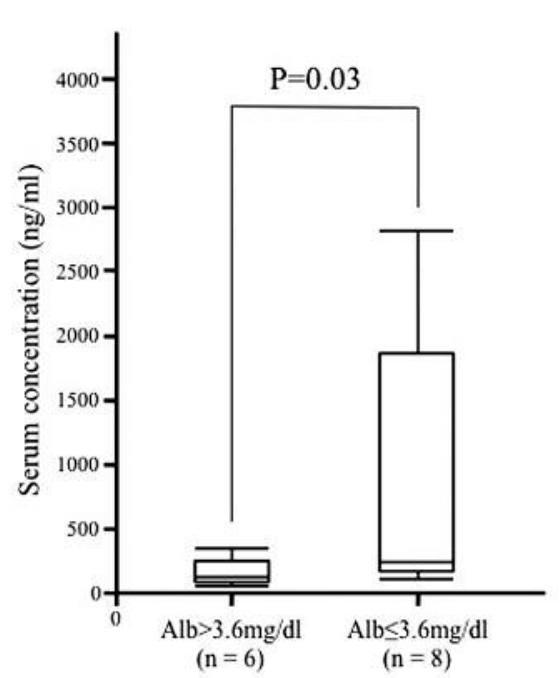

b. Daclatasvir (1week)

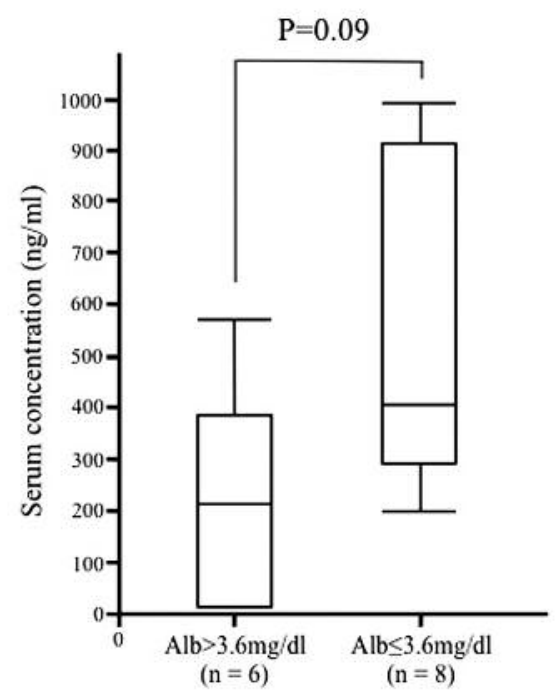

Figure 2. Relationships between serum albumin and asunaprevir and daclatasvir concentrations. a. One week after starting treatment, asunaprevir concentrations were significantly higher in patients with baseline albumin concentrations $\leq 3.6 \mathrm{~g} / \mathrm{dl}$ than in patients with baseline albumin concentrations $>3.6 \mathrm{~g} / \mathrm{dl}(\mathrm{p}=0.03)$. $b$. Daclatasvir concentrations tended to be higher in patients with baseline albumin concentrations $\leq 3.6 \mathrm{~g} / \mathrm{dl}$ than in those with baseline albumin concentrations $>3.6 \mathrm{~g} / \mathrm{dl}(p=0.09) 1$ week after starting treatment.

Table II. Adverse effects during asunaprevir- and daclatasvir-based therapy for recurrent hepatitis $C$ after living-donor liver transplantation.

\begin{tabular}{lccc}
\hline Variables & $\begin{array}{c}\text { Before therapy } \\
(\mathrm{n}=14)\end{array}$ & $\begin{array}{c}24 \mathrm{w} \text { after therapy } \\
(\mathrm{n}=14)\end{array}$ & $p$-Value \\
\hline $\mathrm{Hb}(\mathrm{g} / \mathrm{dl})$ & $11.7 \pm 0.3$ & $12.0 \pm 0.4$ & 0.23 \\
Eosinophil $(\%)$ & $5.2 \pm 1.2$ & $4.3 \pm 0.7$ & 0.92 \\
Total bilirubin (mg/dl) & $1.6 \pm 0.4$ & $0.9 \pm 0.2$ & 0.19 \\
AST (U/l) & $119 \pm 31$ & $34 \pm 3$ & 0.0007 \\
ALT (U/l) & $103 \pm 36$ & $23 \pm 2$ & 0.0015 \\
Cr $(\mathrm{mg} / \mathrm{dl})$ & $1.0 \pm 0.1$ & $1.1 \pm 0.1$ & 0.19 \\
eGFR (ml/min per $\left.1.73 \mathrm{~m}^{2}\right)$ & $51.4 \pm 5.9$ & $48.4 \pm 5.6$ & 0.18 \\
\hline
\end{tabular}

24 w: 24 weeks; AST: aspartate aminotransferase; ALT: alanine aminotransferase; Cr: creatinine; eGFR: estimated glomerular filtration rate. Values are expressed as mean \pm standard error.

correlations between achievement of SVR12 and serum concentrations of asunaprevir or daclatasvir.

Adverse effects. One patient $(7.1 \%)$ had headaches and four patients $(28.6 \%)$ anemia $(\mathrm{Hb}<10 \mathrm{~g} / \mathrm{dl})$ during DAA treatment. However, no patient developed severe anemia $(\mathrm{Hb}<8.5 \mathrm{~g} / \mathrm{dl})$ requiring blood transfusion. Table II shows laboratory data before and after asunaprevir and daclatasvir-based therapy. There were no significant differences in $\mathrm{Hb}$ concentrations, eosinophil percentages, total bilirubin concentrations, creatinine $(\mathrm{Cr})$ concentrations, or estimated glomerular filtration rates (eGFR) before and after this treatment. No liver dysfunction resulting from the administration of asunaprevir and daclatasvir was detected, except in the patient with $\mathrm{HCV}$ relapse after having no virological response. Concentrations of aspartate aminotransferase (AST) and alanine aminotransferase (ALT) were significantly lower after than before DAA treatment ( $p=0.0007$ and $p=0.0015$, respectively).

\section{Discussion}

The availability of first-generation DAAs marked a bright new era for the prognosis of liver transplant recipients with recurrent $\mathrm{HCV}$. It was reported that the patients with SVR 
a. Tacrolimus trough level $(\mathrm{n}=14)$

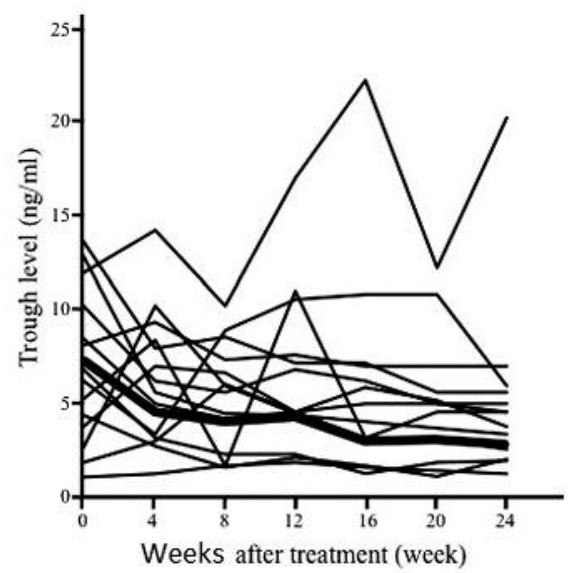

b. Tacrolimus trough/dose ratio $(n=14)$

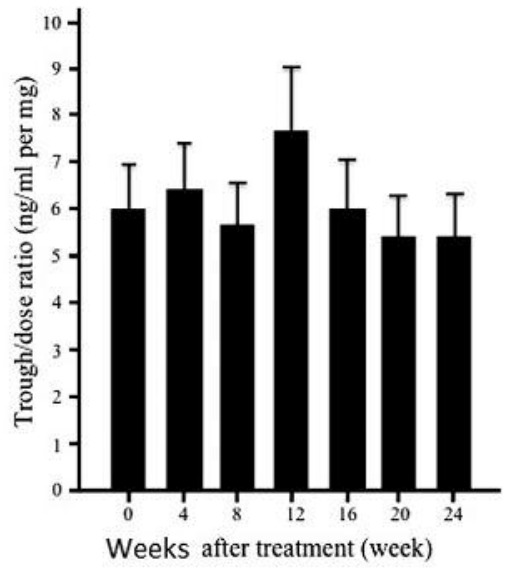

Figure 3. Changes in tacrolimus trough, dose, and trough/dose ratio after starting treatment. a. Changes in tacrolimus dose after the start of treatment. The tacrolimus dose was significantly lower 4 weeks after treatment $(0.9 \pm 0.2 \mathrm{mg} /$ day) than before treatment ( $1.4 \pm 0.3 \mathrm{mg} / \mathrm{day}, \mathrm{p=0.01)}$.

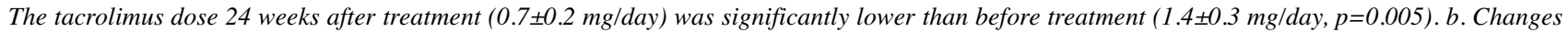
in tacrolimus trough concentrations after starting treatment. The bold line indicates the average tacrolimus trough concentration. The tacrolimus trough concentration was also significantly lower 24 weeks after treatment $(3.5 \pm 0.5 \mathrm{ng} / \mathrm{ml})$ than before treatment $(6.5 \pm 0.9 \mathrm{ng} / \mathrm{ml}$, p=0.003).

a. HCV-RNA level $(n=14)$

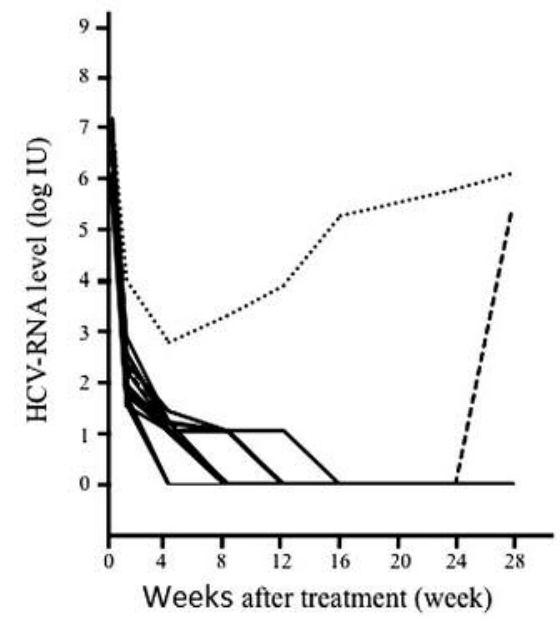

b. HCV-RNA clearance $(\% ; n=14)$

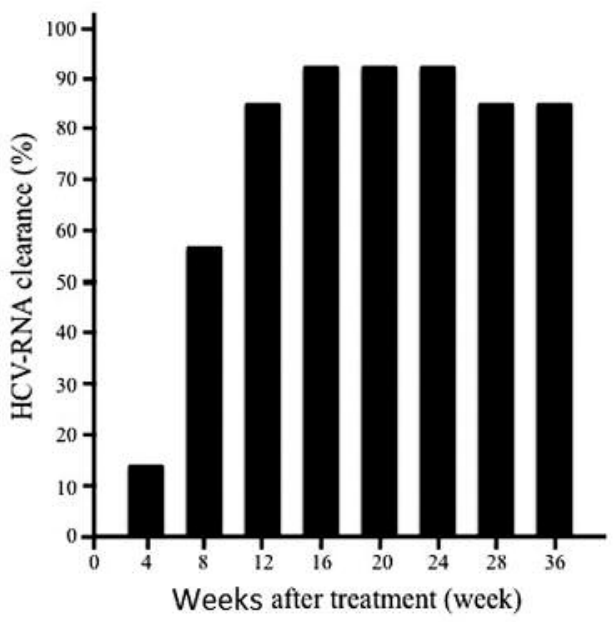

Figure 4. Changes in HCV-RNA titers and HCV-RNA clearance after starting treatment. a. Thirteen liver transplant patients completed the treatment protocol, whereas one discontinued treatment because of absence of virological response $(n=1)$ and viral breakthrough 4 weeks after treatment $(n=1) . b . H C V-R N A$ became undetectable in serum within 16 weeks in $92.9 \%$ of patients. ETVR was achieved in 13 patients (92.9\%) and SVR12 in $12(85.7 \%)$.

had a more favorable long-term prognosis than those without SVR in patients undergoing hepatectomy for hepatocellular carcinoma (21). However, these DAAs are potentially associated with adverse effects and drug-drug interactions (22). Second-generation DAAs improved efficacy of treatment of patients with recurrent $\mathrm{HCV}$ infection after
LDLT (5). Asunaprevir is a potent, second-generation, selective NS3 protease inhibitor with antiviral activity against $\mathrm{HCV}$ genotypes 1, 4, 5, and 6 in vitro (23). Daclatasvir is also a second-generation NS5A replication complex inhibitor with potent pangenotypic antiviral activity in vitro (HCV genotypes 1-6) (24). Both daclatasvir and 
asunaprevir have demonstrated robust antiviral activity and no clinically meaningful pharmacokinetic interactions between them have been identified when co-administered $(23,24)$. HCV genotype 1 is the most common worldwide and the most difficult to treat; genotype $1 \mathrm{~b}$ is the most common subtype of genotype 1 outside North America (25). Approximately $10 \%$ of patients with hepatitis $\mathrm{C}$ have genotype $1 \mathrm{~b}$ virus and transplant recipients with genotype $1 \mathrm{~b}$ require treatment with antiviral drugs such as direct acting antivirals after liver transplantation. Hepatitis C always recurs after liver transplantation and it is difficult to treat recurrent hepatitis $C$ of genotype $1 \mathrm{~b}$ in patients with renal dysfunction (glomerular filtration rate (GFR) less than 30 $\mathrm{ml} / \mathrm{min} / 1.73 \mathrm{~m}^{2}$ ) other than with a combination of asunaprevir and daclatasvir.

To our knowledge, this is the first article reporting both serum concentrations of asunaprevir and daclatasvir during combination treatment of patients with recurrent hepatitis $\mathrm{C}$ after LDLT and trough concentrations of tacrolimus. Our patients achieved SVR while taking standard doses of asunaprevir and daclatasvir. Thus far, the lowest effective serum concentration of DAAs has remained unclear; however, in our studies the serum concentrations of DAAs achieved were sufficient to achieve SVR. We assessed serum concentrations of DAAs at three time points during treatment. Our findings suggest that achieving serum concentrations of asunaprevir of greater than $500 \mathrm{ng} / \mathrm{ml}$ and of daclatasvir of greater than $400 \mathrm{ng} / \mathrm{ml}$ by repeated administration of each DAA enables achievement of SVR regardless of the condition of the transplant recipient. The high rates of achieving SVR in our study made it difficult to accurately determine effective serum concentrations of these DAAs. However, serum concentrations of asunaprevir were associated with pretreatment serum albumin concentrations. Asunaprevir binds to serum albumin and is taken up by hepatocytes after oral administration. Consequently, the serum concentration of asunaprevir is thought to be higher when the serum concentration of the binding protein (albumin) is low; as a result, liver uptake of asunaprevir is reduced. In our study, even transplant patients with poor liver function (i.e., serum albumin $<3.6 \mathrm{mg} / \mathrm{ml}$ ) achieved SVR12 and these patients had few adverse effects despite having higher serum concentrations of asunaprevir and daclatasvir. To the best of our knowledge, there are only two published reports about the relationship between serum concentration of asunaprevir and albumin $(26,27)$ and none about the relationship between serum concentration of other DAAs and albumin while receiving immunosuppressive agents such as tacrolimus.

As for the significant difference in asunaprevir concentrations 4 and 12 weeks after starting treatment, we found that blood concentrations of asunaprevir increased slowly approximately one week after repeating the dose of asunaprevir, after which serum albumin concentrations increased significantly, as has been reported by several other groups $(26,27)$. We consider this increase is attributable to improvement in liver function as a result of achieving SVR 4 weeks after the treatment (Figure 4). As a result of interaction with serum albumin concentrations, the serum asunaprevir concentration decreased between 4 weeks and 12 weeks after starting treatment.

As for tacrolimus trough concentrations during treatment with asunaprevir and daclatasvir, according to Ueda et al. it is postulated that the mechanism for the decrease in concentration of tacrolimus is increased metabolism of this calcineurin inhibitor as a result of improved liver function $(28,29)$.

Increase in ALT concentration is the most frequent adverse event during all-oral treatment with asunaprevir and daclatasvir in patients with HCV infection $(5,13)$. In this study, no patients had high ALT concentrations while having combined treatment with asunaprevir and daclatasvir. Additionally, no correlation between ALT and asunaprevir and daclatasvir serum concentrations was found.

The positive findings of this study notwithstanding, asunaprevir and daclatasvir-based therapies still have some limitations. First, pre-existence of a drug-resistant amino acid substitution at NS3-D168, NS5A-L31, or NS5A-Y93 is associated with failure of treatment with asunaprevir and daclatasvir-based therapies (13). Consequently, testing for these substitutions is recommended before treating patients with recurrent hepatitis $\mathrm{C}$ after LDLT. Second, viral breakthrough occurred in one of our patients after asunaprevir and daclatasvir-based treatment. This patient had been a non-responder to previous simeprevir with PEG IFN plus RBV therapy. Moreover, one patient had a NS3-D168 substitution and had been a non-responder to previous treatment using simeprevir with PEG IFN plus RBV. After confirming that the NS3-D168 variation had disappeared, asunaprevir and daclatasvir-based treatment was administered to this patient, who subsequently achieved SVR12. Thus, caution is needed when administering asunaprevir and daclatasvir to non-responders to previous simeprevir with PEG IFN plus RBV therapy.

Third, asunaprevir and daclatasvir-based therapy achieves a high rate of virological response in patients infected with genotype $1 \mathrm{~b} \mathrm{HCV}$; however, this therapy is known to be less effective against genotype 1a HCV. The SVR rate for asunaprevir and daclatasvir therapy in genotype $1 \mathrm{a} \mathrm{HCV-}$ infected patients is reportedly $22 \%$ (30). Fourth, concomitant use of cyclosporin A with asunaprevir is prohibited because of reduced liver uptake of asunaprevir (31). In the current study, we substituted tacrolimus for cyclosporine for immunosuppression before beginning asunaprevir and daclatasvir-based therapy. No major adverse events, such as ACR, were encountered with this protocol. Fifth, tacrolimus trough concentrations tended to increase after the start of asunaprevir and daclatasvir-based treatment in the patient with 
liver cirrhosis (F4); however, liver function did not deteriorate. Special caution is necessary when administering asunaprevir and daclatasvir to transplant patients with liver cirrhosis.

In the present study, asunaprevir and daclatasvir-based therapy had no adverse effects on renal function. Sofosbuvir has a potent inhibitory effect on $\mathrm{HCV}$ replication, and combination treatment with ledipasvir reportedly achieves a high virological response rate in genotype $1 \mathrm{HCV}$-infected patients (10). However, patients with renal dysfunction (eGFR $<30 \mathrm{ml} / \mathrm{min}$ per $1.73 \mathrm{~m}^{2}$ ) are ineligible for sofosbuvir therapy. Therefore, we recommend asunaprevir and daclatasvir-based therapy as a suitable alternative therapy for patients infected with genotype $1 \mathrm{~b} \mathrm{HCV}$ with renal dysfunction.

Our study has some limitations, including the small number of patients in a particular setting (i.e., post-LDLT) and potential bias in the selection of patients to receive asunaprevir and daclatasvir-based therapy. Our study was conducted at a single center, allowing us to monitor patients carefully and maintain consistent patient management, which may not be possible in a multicenter study.

In conclusion, in our cohort of 14 patients asunaprevir and daclatasvir-based therapy with tacrolimus for recurrent hepatitis $\mathrm{C}$ after LDLT was associated with few adverse events and no drug-drug interactions and resulted in good antiviral control in 13 of the 14. Cross-resistance to asunaprevir resulting from a NS5A variant is a significant clinical problem that warrants particular caution following LDLT.

\section{Conflicts of Interest}

The Authors have no conflicts of interest to disclose.

\section{Acknowledgements}

The Authors thank Bristol-Myers Squibb Company for measuring serum concentrations of asunaprevir and daclatasvir. The Authors also thank Dr. Trish Reynolds, MBBS, FRACP, from Edanz Group (www.edanzediting.com/ac) for editing a draft of this manuscript. This work was supported by a Grant-in-Aid for Scientific Research from the Ministry of Health, Labour and Welfare, Japan (17fk0210107 h0001).

\section{References}

1 Kim S, Han KH and Ahn SH: Hepatitis C Virus and Antiviral Drug Resistance. Gut Liver 10: 890-895, 2016.

2 Manns MP, McHutchison JG, Gordon SC, Rustgi VK, Shiffman M, Reindollar R, Goodman ZD, Koury K, Ling M and Albrecht $\mathrm{JK}$ : Peginterferon alfa-2b plus ribavirin compared with interferon alfa- $2 b$ plus ribavirin for initial treatment of chronic hepatitis C: a randomised trial. Lancet 358: 958-965, 2001.

3 Fried MW, Shiffman ML, Reddy KR, Smith C, Marinos G, Gonçales FL Jr, Häussinger D, Diago M, Carosi G, Dhumeaux D, Craxi A, Lin A, Hoffman J and Yu J: Peginterferon alfa-2a plus ribavirin for chronic hepatitis $\mathrm{C}$ virus infection. N Engl J Med 347: 975-982, 2002.
4 Berenguer M, Ferrell L, Watson J, Prieto M, Kim M, Rayón M, Córdoba J, Herola A, Ascher N, Mir J, Berenguer J and Wright TL: $\mathrm{HCV}$-related fibrosis progression following liver transplantation: increase in recent years. J Hepatol 32: 673-684, 2000.

5 Ueda Y, Kaido T, Hatano E, Ohtsuru S and Uemoto S: Safe and effective treatment with daclatasvir and asunaprevir in a liver transplant recipient with severe cholestatic hepatitis C. Hepatol Res 45: 1360-1362, 2015.

6 Jacobson IM, McHutchison JG, Dusheiko G, Di Bisceglie AM, Reddy KR, Bzowej NH, Marcellin P, Muir AJ, Ferenci P, Flisiak R, George J, Rizzetto M, Shouval D, Sola R, Terg RA, Yoshida EM, Adda N, Bengtsson L, Sankoh AJ, Kieffer TL, George S, Kauffman RS and Zeuzem S; ADVANCE Study Team: Telaprevir for previously untreated chronic hepatitis C virus infection. N Engl J Med 364: 2405-2416, 2011.

7 Crespo G, Mariño Z, Navasa M and Forns X: Viral hepatitis in liver transplantation. Gastroenterology 142: 1373-1383, 2012.

8 Berenguer M, Palau A, Aguilera V, Rayón JM, Juan FS and Prieto M: Clinical benefits of antiviral therapy in patients with recurrent hepatitis $\mathrm{C}$ following liver transplantation. Am J Transplant 8: 679-687, 2008.

9 Schmidt SC, Bahra M, Bayraktar S, Berg T, Schmeding M, Pratschke J, Neuhaus P and Neumann U: Antiviral treatment of patients with recurrent hepatitis $\mathrm{C}$ after liver transplantation with pegylated interferon. Dig Dis Sci 55: 2063-2069, 2010.

10 Charlton M, Everson GT, Flamm SL, Kumar P, Landis C, Brown RS Jr, Fried MW, Terrault NA, O'Leary JG, Vargas HE, Kuo A, Schiff E, Sulkowski MS, Gilroy R, Watt KD, Brown K, Kwo P, Pungpapong S, Korenblat KM, Muir AJ, Teperman L, Fontana RJ, Denning J, Arterburn S, Dvory-Sobol H, Brandt-Sarif T, Pang PS, McHutchison JG, Reddy KR and Afdhal N; SOLAR1 Investigators: Ledipasvir and sofosbuvir plus ribavirin for treatment of $\mathrm{HCV}$ infection in patients with advanced liver disease. Gastroenterology 149: 649-659, 2015.

11 Kwo PY, Mantry PS, Coakley E, Te HS, Vargas HE, Brown R Jr, Gordon F, Levitsky J, Terrault NA, Burton JR Jr, Xie W, Setze C, Badri P, Pilot-Matias T, Vilchez RA and Forns X: An interferon-free antiviral regimen for $\mathrm{HCV}$ after liver transplantation. N Engl J Med 371: 2375-2382, 2014.

12 Pellicelli AM, Montalbano M, Lionetti R, Durand C, Ferenci P, D’Offizi G, Knop V, Telese A, Lenci I, Andreoli A, Zeuzem S and Angelico M: Sofosbuvir plus daclatasvir for post-transplant recurrent hepatitis C: Potent antiviral activity but no clinical benefit if treatment is given late. Dig Liver Dis 46: 923-927, 2014.

13 Kumada H, Suzuki Y, Ikeda K, Toyota J, Karino Y, Chayama K, Kawakami Y, Ido A, Yamamoto K, Takaguchi K, Izumi N, Koike K, Takehara T, Kawada N, Sata M, Miyagoshi H, Eley T, McPhee F, Damokosh A, Ishikawa H and Hughes E: Daclatasvir plus asunaprevir for chronic HCV genotype $1 \mathrm{~b}$ infection. Hepatology 59: 2083-2091, 2014.

14 Scheuer PJ: Classification of chronic viral hepatitis: a need for reassessment. J Hepatol 13: 372-374, 1991.

15 Ikegami T, Shirabe K, Yamashita Y, Yoshizumi T, Harimoto N, Takeishi K, Tsujita E, Itoh S and Maehara Y: Small upper midline incision for living donor hemi-liver graft procurement in adults. J Am Coll Surg 219: e39-43, 2014.

16 Ikegami T, Soejima Y, Taketomi A, Yoshizumi T, Harada N, Uchiyama H, Shimada M and Maehara Y: Explanted portal vein grafts for middle hepatic vein tributaries in living-donor liver transplantation. Transplantation 84: 836-841, 2017. 
17 Ikegami T, Shirabe K, Soejima Y, Yoshizumi T, Uchiyama H, Yamashita Y, Harimoto N, Toshima T, Yoshiya S, Ikeda T and Maehara Y: Strategies for successful left-lobe living donor liver transplantation in 250 consecutive adult cases in a single center. J Am Coll Surg 216: 353-362, 2013.

18 Eley T, He B, Huang SP, Li W, Pasquinelli C, Rodrigues AD, Grasela DM and Bertz RJ: Pharmacokinetics of the NS3 protease inhibitor, Asunaprevir (ASV, BMS-650032), in phase i studies in subjects with or without chronic hepatitis C. Clin Pharmacol Drug Dev 2: 316-327, 2013.

19 Shiozaki T, Ueno T, Nagashima H, Yamahira N, Hiraoka M, Eley T, Bifano M and Bertz RJ: Single- and multiple-ascending dose studies to evaluate the safety, tolerability, and pharmacokinetics of daclatasvir and asunaprevir in healthy male Japanese subjects. Int J Clin Pharmacol Ther 53: 292-302, 2015.

20 Selzner N, Guindi M, Renner EL and Berenguer M: Immunemediated complications of the graft in interferon-treatedhepatitis $\mathrm{C}$ positive liver transplant recipients. J. Hepatol 55: 207-217, 2011.

21 Kimura K, Itoh S, Kurihara T, Yoshida Y, Wang H, Harimoto N, Nishie A, Shirabe K, Oda Y and Maehara Y: favorable prognosis in patients with sustained virological response to antiviral therapy, including interferon, for chronic hepatitis c before hepatic resection for hepatocellular carcinoma. Anticancer Res 35: 6963-6969, 2015.

22 Ikegami T, Yoshizumi T, Yoshida Y, Kurihara T, Harimoto N, Itoh S, Shimokawa M, Fukuhara T, Shirabe K and Maehara Y: Telaprevir versus simeprevir for the treatment of recurrent hepatitis $\mathrm{C}$ after living donor liver transplantation. Hepatol Res 46: E136-145, 2016.

23 McPhee F, Sheaffer AK, Friborg J, Hernandez D, Falk P, Zhai G, Levine S, Chaniewski S, Yu F, Barry D, Chen C, Lee MS, Mosure K, Sun LQ, Sinz M, Meanwell NA, Colonno RJ, Knipe $\mathrm{J}$ and Scola P: Preclinical profile and characterization of the hepatitis C virus NS3 protease inhibitor Asunaprevir (BMS650032). Antimicrob Agents Chemother 56: 5387-5396, 2012.

$24 \mathrm{Gao} \mathrm{M}$ : Antiviral activity and resistance of HCV NS5A replication complex inhibitors. Curr Opin Virol 3: 514-520, 2013.
25 Chayama K, Takahashi S, Toyota J, Karino Y, Ikeda K, Ishikawa H, Watanabe H, McPhee F, Hughes E and Kumada H: Dual therapy with the nonstructural protein $5 \mathrm{~A}$ inhibitor, daclatasvir, and the nonstructural protein 3 protease inhibitor, asunaprevir, in hepatitis $\mathrm{C}$ virus genotype $1 \mathrm{~b}$-infected null responders. Hepatology 55: 742-748, 2012.

26 Akuta N, Sezaki H, Suzuki F, Kawamura Y, Hosaka T, Kobayashi M, Kobayashi M, Saitoh S, Suzuki Y, Arase Y, Ikeda $\mathrm{K}$ and Kumada H: Relationships between serum asunaprevir concentration and alanine aminotransferase elevation during daclatasvir plus asunaprevir for chronic HCV genotype $1 \mathrm{~b}$ infection. J Med Virol 88: 506-511, 2016.

27 Kan T, Hashimoto S, Kawabe N, Nakano T, Nakaoka K and Yoshioka K: Increase in albumin by daclatasvir/asunaprevir therapy is correlated with decrease in aspartate transaminase. J Transl Int Med 5: 148-154, 2017.

28 Kugelmas M, Osgood MJ, Trotter JF, Bak T, Wachs M, Forman L, Kam I and Everson GT: Hepatitis C virus therapy, hepatocyte drug metabolism, and risk for acute cellular rejection. Liver Transpl 9: 1159-1165, 2003.

29 Ueda Y, Kaido $\mathrm{T}$ and Uemoto $\mathrm{S}$ : Fluctuations in the concentration/dose ratio of calcineurin inhibitors after simeprevir administration in patients with recurrent hepatitis $\mathrm{C}$ after liver transplantation. Transplant Int 28: 251-252, 2015.

30 Lok AS, Gardiner DF, Lawitz E, Martorell C, Everson GT, Ghalib R, Reindollar R, Rustgi V, McPhee F, Wind-Rotolo M, Persson A, Zhu K, Dimitrova DI, Eley T, Guo T, Grasela DM and Pasquinelli C: Preliminary study of two antiviral agents for hepatitis C genotype 1. N Engl J Med 366: 216-224, 2012.

31 Ferenci P: Treatment of chronic hepatitis $\mathrm{C}$ - are interferons really necessary? Liver Int 32: 108-112, 2012.

Received July 5, 2018

Revised July 23, 2018

Accepted July 25, 2018 